\title{
Detection of human bocavirus from children and adults with acute respiratory tract illness in Guangzhou, southern China
}

Wen-Kuan Liu ${ }^{1,2}$, De-Hui Chen², Qian Liu ${ }^{1,2}$, Huan-Xi Liang ${ }^{1,2}$, Zi-Feng Yang ${ }^{1,2}$, Sheng Qin ${ }^{1,2}$ and Rong Zhou ${ }^{1,2^{*}}$

\begin{abstract}
Background: Human bocavirus ( $\mathrm{HBOV}$ ) is a newly discovered parvovirus associated with acute respiratory tract illness (ARTI) and gastrointestinal illness. Our study is the first to analyze the characteristics of HBoV-positive samples from ARTI patients with a wide age distribution from Guangzhou, southern China.

Methods: Throat swabs $(n=2811)$ were collected and analyzed from children and adults with ARTI over a 13-month period. The HBoV complete genome from a 60 year-old female patient isolate was also determined.

Results: HBoV DNA was detected in 65/2811 (2.3\%) samples, of which 61/1797 were from children ( $<18$ years old) and $4 / 1014$ from adults ( $\geq 18$ years old). Seasonal peaks of $4.8 \%$ and $7.7 \%$ were detected in May and June, respectively. 28 of 65 (43.1\%) HBoV-positive samples were co-detected with 11/16 other potential pathogens. Mycoplasma pneumoniae had the highest frequency of 16.9\% (11/65). Upper and lower respiratory tract illness were common symptoms, with 19/65 (29.2\%) patients diagnosed with pneumonia by chest radiography. All four adult patients had systemic influenza-like symptoms. Phylogenetic analysis of the complete genome revealed a close relationship with other $\mathrm{HBOV}$, and a more distant relationship with HBoV2 and HBoV3.

Conclusions: HBoV was detected from children and adults with ARTI from Guangzhou, southern China. Elderly people were also susceptive to HBoV. A single lineage of HBoV was detected among a wide age distribution of patients with ARTI.
\end{abstract}

\section{Background}

Respiratory tract infection etiology is complex and diverse, and new pathogens are continuously being reported. Over the past few years, several novel respiratory viruses including human metapneumovirus (hMPV) [1], severe acute respiratory syndrome (SARS) coronavirus [2], human coronavirus NL63 (HCoV-NL63) [3,4], and coronavirus HKU1 (HCoV-HKU1) [5-7] have been identified.

In 2005, Allander et al. [8] reported a previously undescribed human parvovirus, human bocavirus (HBoV) that belongs to the genus Bocavirus, in respiratory secretions of children with respiratory tract disease in Sweden. HBoV is a single-stranded deoxyribonucleic acid (DNA) virus with a small genome size of approximately 5.3 kilo-bases $(\mathrm{kb})$, which has three open reading frames (ORF) encoding

\footnotetext{
* Correspondence: zhou3218@yahoo.com

'State Key Laboratory of Respiratory Diseases, Guangzhou Medical University,

1 Kang Da Road, Guangzhou, Guangdong 510230, China

Full list of author information is available at the end of the article
}

two non-structural proteins NS1 and NP1, and the two structural proteins VP1 and VP2. VP1 and VP2 are located within the same ORF but have different initiator codon positions [8].

Subsequently, $\mathrm{HBoV}$ was reported in respiratory samples from different countries and regions worldwide [9-14], where $\mathrm{HBoV}$ was detected in $1.5 \%-8.3 \%$ of respiratory samples from individuals with acute respiratory tract illness (ARTI), especially young children and infants. The virus was also found in stool samples from patients with gastrointestinal illness [15-22]. These reports suggest that $\mathrm{HBoV}$ might be associated with upper and lower respiratory disease and gastrointestinal illness throughout the world. In 2009, two viruses closely related to $\mathrm{HBoV}$, named HBoV2 [23] and HBoV3 [24], were found in stool samples, and suggested $\mathrm{HBoV}$ diversity.

$\mathrm{HBoV}$ infection has recently attracted increasing attention all over the world. However, the incidence and clinical presentation of this infection varies widely, and often

\section{Biomed Central}

(c) 2011 Liu et al; licensee BioMed Central Ltd. This is an Open Access article distributed under the terms of the Creative Commons Attribution License (http://creativecommons.org/licenses/by/2.0), which permits unrestricted use, distribution, and reproduction in any medium, provided the original work is properly cited. 
involves co-infection with other potential pathogens [9-22]. Such characteristics have led to debate over the role of $\mathrm{HBoV}$ as a true pathogen. Therefore, additional evidence and studies are needed throughout the world to gain a better understanding of this virus. In this study, 2811 respiratory samples were collected from patients (with an age range of 9 days to 84 years) with ARTI in Guangzhou, southern China, from November 2009 to November 2010 to analyze the characteristics of HBoVpositive patients.

\section{Methods}

Samples in this study were taken as part of standard care. The First Affiliated Hospital of Guangzhou Medical University Ethics Committee approved the experimental design and patient involvement in this study.

\section{Respiratory samples collection}

Throat swab samples $(n=2811)$ were collected from patients with ARTI (presented at least two of the following symptoms: cough, pharyngeal discomfort, rhinobyon, snivel, sneeze, dyspnea) at three hospitals in Guangzhou, southern China between November 2009 and November 2010. Patients' ages ranged from nine days to 84 years, and included 1797 children ( $<18$-years-old) and 1014 adults ( $\geq 18$-years-old). Clinical characteristics of the patients were recorded for further analysis.

\section{Real-time polymerase chain reaction (PCR) for HBoV detection}

DNA from respiratory samples was extracted using a QIAamp DNA Mini Kit (Qiagen), in accordance with the manufacturer's protocol. Taqman real-time PCR primers and probe were designed based on the conserved region of the NP1 gene. Sequences were as follows: forward primer, 5'- GAG AGA GGC TCG GGC TCA TA-3' (25452564 nt); reverse primer, 5' - TCG AAG CAG TGC AAG ACG AT-3' (2592-2611 nt); and probe, 5'-FAM- CAT CAG GAA CAC CCA ATC AGC CAC C-BHQ1-3' (2566-2590 nt). Primers and the probe were synthesized by TaKaRa. Premix Ex Taq (Perfect Real Time) real-time PCR reaction buffer was also purchased from TaKaRa. Amplification was conducted using 10 pmol of primers, 3 pmol of probe and $5 \mu \mathrm{l}$ DNA in a final volume of $25 \mu \mathrm{l}$. Cycling conditions included an initial incubation at $94^{\circ} \mathrm{C}$ for $2 \mathrm{~min}$, followed by 40 cycles of $94^{\circ} \mathrm{C}$ for $10 \mathrm{sec}$ and $55^{\circ} \mathrm{C}$ for $35 \mathrm{sec}$ (ABI-7500 real-time PCR instrument, Applied Biosystems). The amplified NP1 gene target sequence (2545-2611 nt) was inserted into the pMD18-T vector (TaKaRa) and used as a positive control for quantification analysis. Sensitivity of the PCR assay was calculated to be 10 copies of plasmid DNA using positive control plasmid diluted gradients.

\section{Detection of common respiratory pathogens in HBoV- positive samples}

HBoV DNA positive samples were tested for 16 other potential pathogens, including influenza A virus, influenza B virus, parainfluenza virus $(1,2,3,4)$, respiratory syncytial virus, adenovirus, enterovirus, human metapneumovirus, human coronavirus (229E, OC43, NL63, HKU1), Mycoplasma pneumoniae, and Chlamydia pneumoniae by Taqman real-time PCR, in accordance with the manufacturer's protocol (Guangzhou HuYanSuo Medical Technology Co., Ltd).

\section{Complete genome sequencing}

The complete genome of $\mathrm{HBoV}$ from a 60 -year-old female patient isolate was sequenced and analyzed. Sequencing primer sets were designed according to $\mathrm{HBoV}$ genome sequences available in the GenBank database (Table 1). DNA template $(2 \mu \mathrm{l})$ was added to the Pfu DNA polymerase reaction mixture (Fermentas) in a final volume of 25 $\mu \mathrm{l}$ and PCR amplified. Products were purified after $1 \%$ agarose gel electrophoresis using a QIAquick Gel Extraction Kit (Qiagen). The purified DNA was then sequenced (ABI Genetic Analyzer 3130XL) and assembled using DNASTAR-SeqMan software (DNASTAR, http://www. dnastar.com/t-products-lasergene.aspx). PCR amplification and sequencing were conducted at least twice to ensure sequence accuracy.

\section{Phylogenetic analysis}

The HBoV complete genome (GU338055) was aligned to other $\mathrm{HBoV}$ genomes available in the GenBank database using the Basic Local Alignment Search Tool (BLAST, http://blast.ncbi.nlm.nih.gov/Blast.cgi). Phylogenetic analysis of 18 complete genomes of $\mathrm{HBoV}, \mathrm{HBoV} 2$ and $\mathrm{HBoV} 3$ from different countries and regions, including USA, Sweden, Thailand, Japan, Australia, China, Hong Kong, and Taiwan was conducted using Molecular Evolutionary Genetics Analysis Version 4.0 (MEGA 4.0, http://www. megasoftware.net/). Phylogenetic trees were inferred from VP1/VP2 (3056-5071 nt), NS1 (253-2172 nt), NP1 gene (2410-3069 nt) and complete genome data (1-5299 nt) using the neighbor-joining method, and bootstrap values were calculated from 1000 replicates.

\section{Statistical analysis}

For comparison of categorical data, $\chi^{2}$ test and Fisher's exact test where appropriate. All tests were two-tailed and $p<0.05$ was considered statistical significant.

\section{Results}

\section{Detection of HBoV from patients with ARTI}

HBoV DNA positive samples were detected in $65 / 2811$ patients with a total positive rate of $2.3 \%$. In children, 
Table 1 Primer sets for HBoV genome sequencing

\begin{tabular}{|c|c|c|c|}
\hline Primers & Sequences & Amplification position (bases) & Product length \\
\hline VF1 & 5'-GCCGGCAGACATATTGGA-3' & $1-1460$ & 1460bp \\
\hline VR1 & 5'-TGACCAACGGCTAGAGGATTA-3' & & \\
\hline $\mathrm{VF2}$ & 5'-ATGCTAAATCATCCTGTG-3' & $638-2435$ & 1798bp \\
\hline VR2 & 5'-TTGTCTTTCATATTCCCT-3' & & \\
\hline VF3 & 5'-ACCCAAGAAACGTCGTCTAACTG-3' & $2300-4226$ & $1927 b p$ \\
\hline VR3 & 5'-TTAGTCCAGGAGGAATGTATGCT-3' & & \\
\hline VF4 & 5'-GGAGGCAATGCTACAGAAA-3' & 4064-5299 & $1236 \mathrm{bp}$ \\
\hline VR4 & 5'-TGTACAACAACAACACATTAAAAG-3' & & \\
\hline
\end{tabular}

positive rates were $4.1 \%(28 / 687)$ for 0 -1 year-olds, $>4.8 \%(16 / 335)$ for $1-2$ year-olds, $4.4 \%(10 / 225)$ for $>2$ 3 year-olds, $1.7 \%(2 / 121)$ for $>3-4$ year-olds, $1.3 \%(1 / 80)$ for $>4-5$ year-olds, and $1.1 \%$ (4/349) for $>5-17$ year-olds (Figure 1), with a total of $3.4 \%(61 / 1797)$. The positive rate of adults ( $\geq 18$ year-old) was $0.4 \%(4 / 1014)$ (Figure 1).

The 65 positive patients were aged between 54 days and 70 years, comprising $83.1 \%(54 / 65)$ that were $\leq 3$ years-old, $10.8 \%(7 / 65)$ that were $4-17$ years-old, and $6.2 \%(4 / 65)$ adult patients. Four $\mathrm{HBoV}$-positive adults were 19, 22, 60 and 70 years-old, respectively.

\section{Seasonal distribution of HBoV}

During our 13-month study period, more than 100 samples were collected for detection each month, and the ratio of $\leq 3$ year-old patients ranged from $20.2 \%$ to $66.5 \%$. Low positive rates of $0.3 \%(1 / 369)$ (single HBoV: 0, co-pathogen: $0.3 \%)$ were detected in March 2010 and $0.7 \%$ (1/135) (single HBoV: $0.7 \%$, co-pathogen: 0 ) in October 2010, while high positive rates of $4.8 \%(8 / 166)$ (single $\mathrm{HBoV}: 3.0 \%$, co-pathogens: $1.8 \%$ ) were found in May 2010 and 7.7\% (11/143) (single HBoV: 1.4\%, copathogens: $6.3 \%$ ) in June 2010 (Figure 2). The positive rates of other seven months fluctuated around the total rate of 2.3\% (65/2811) (Figure 2).

\section{Co-detection with common respiratory pathogens}

HBoV DNA positive samples were co-detected with 11 of 16 upper referred pathogens in 28/65 (43.1\%) of the patients. Mycoplasma pneumoniae had the highest frequency of $16.9 \%$ (11/65), followed by RSV with $7.7 \%$ (5/ 65) (Table 2).

The clinical characteristics of HBoV-positive patients

The male:female ratio was 42:23 in the $\mathrm{HBoV}$-positive patients which did not differ significantly from the HBoV-negative patients $(p=0.40)$. The clinical characteristics of the patients are listed in Table 3. Most patients presented with symptoms of upper respiratory tract illness (URTI), including cough (93.8\%) and expectoration $(40.0 \%) ; 44(67.7 \%)$ patients presented with

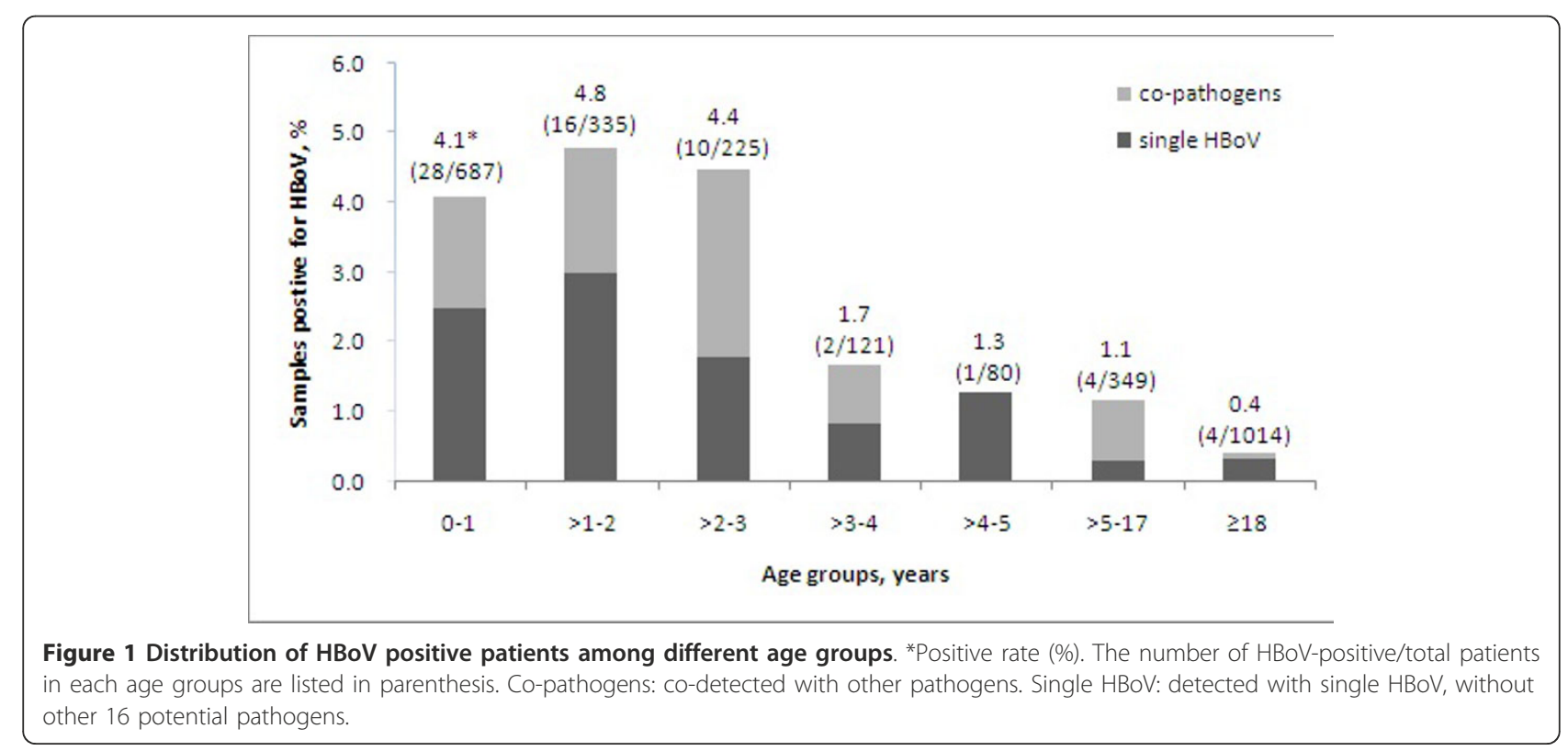




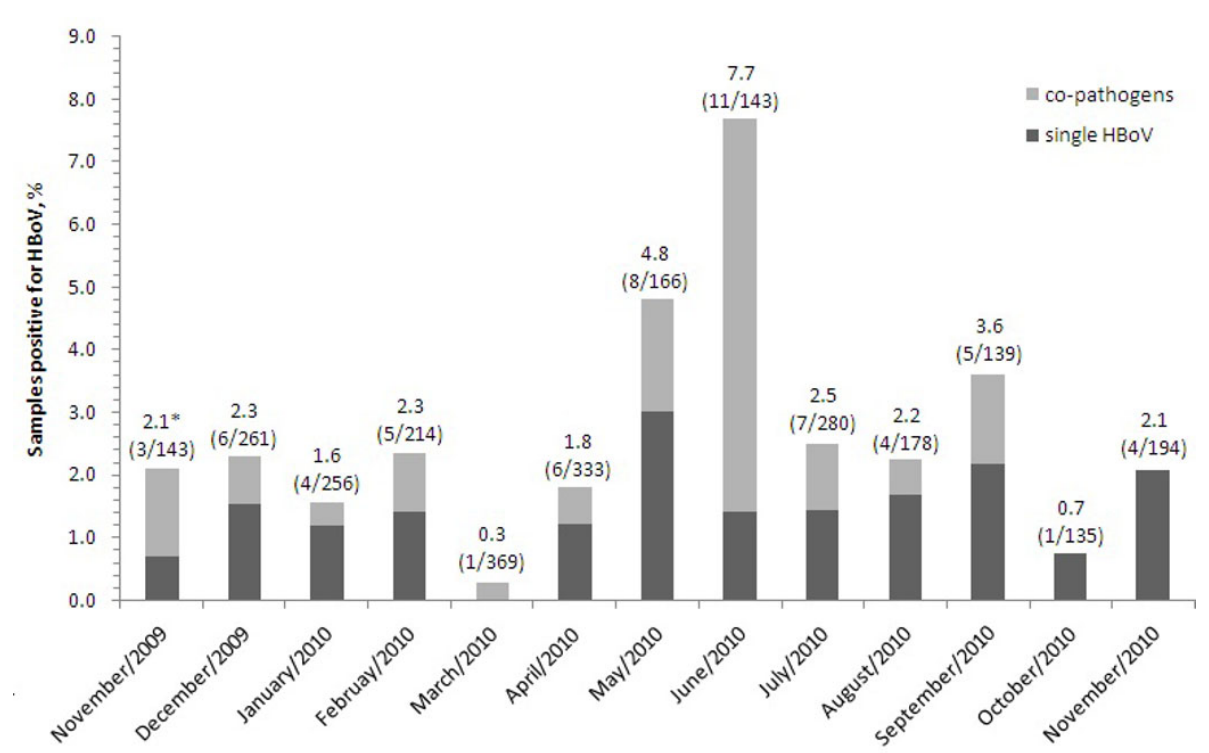

Figure 2 Seasonal distribution of HBoV from November 2009 to November 2010. *Positive rate (\%). The number of HBoV-positive/total patients in 13 months are listed in parenthesis. Co-pathogens: co-detected with other pathogens. Single HBoV: detected with single HBoV, without other 16 potential pathogens.

symptoms of fever $\left(\geq 38^{\circ} \mathrm{C}\right) ; 41$ (63.1\%) patients had lower respiratory tract illness symptoms (LRTI) and 19 (29.2\%) patients were diagnosed as pneumonia by chest radiography; 10 (15.4\%) patients had gastrointestinal symptoms; seven $(10.8 \%)$ patients had systemic influenza-like symptoms (chilly, swirl, headache, myodynia or debilitation); and one (1.5\%) patient had herpetic angina.

Abnormal pulmonary breathing sounds and dyspnea were detected in 35 (53.9\%) and $30(46.2 \%)$ of 65 patients, respectively (Table 3 ). Nineteen $(29.2 \%)$ were diagnosed as pneumonia by chest radiography, and 13/ 19 (68.4\%) pneumonia patients were co-detected with one or two other pathogens, and a statistic difference was found for the symptom of "pneumonia" $(p=0.008)$ between the two groups "Single HBoV" and "Co-

Table 2 Co-pathogens of HBoV-positive patients

\begin{tabular}{lr}
\hline Co-pathogens & Patient \\
\hline Mycoplasma pneumoniae & $11(16.9)$ \\
\hline Respiratory syncytial virus & $5(7.7)$ \\
\hline Parainfluenza virus type 3 & $4(6.2)$ \\
\hline Enterovirus & $4(6.2)$ \\
\hline Influenza A virus & $3(4.6)$ \\
\hline Human coronavirus OC43 & $3(4.6)$ \\
\hline Human coronavirus HKU1 & $3(4.6)$ \\
\hline Adenovirus & $2(3.1)$ \\
\hline Human metapneumovirus & $2(3.1)$ \\
\hline Influenza B virus & $1(1.5)$ \\
\hline Parainfluenza virus type 1 & $1(1.5)$ \\
\hline
\end{tabular}

pathogens". Two of seven patients with systemic influenza-like symptom samples were co-detected with influenza A virus-enterovirus (triple pathogens) and influenza B virus (dual pathogens), respectively, while the remaining five patients were detected with single HBoV. All four adult patients ( $\geq 18$ years old) presented with systemic influenza-like symptoms; three had only HBoV detection and the other 19 year-old female patient was co-detected with influenza B virus.

\section{Complete genome sequencing and phylogenetic analysis}

Complete $\mathrm{HBoV}$ genome sequences for isolates from a 60 year-old patient were sequenced and submitted to the GeneBank (Accession Number:GU338055). The full length of the genome was 5299 bases and the distribution of $\mathrm{A} / \mathrm{G} / \mathrm{C} / \mathrm{T}$ was $32.4 \% / 20.4 \% / 21.8 \% / 25.4 \%$, respectively. Compared to the other $\mathrm{HBoV}$ genomes available in the GeneBank database, GU330588 showed a 98\% similarity with the $\mathrm{HBoV}$ previously described by Allander et al. [8]. Phylogenetic trees were inferred from VP1/VP2, NS1, and NP1 gene data, in addition to the complete genome sequence (Figure 3). GU330588 was similar to other $\mathrm{HBoVs}$, although it displayed obviously sequence variations from $\mathrm{HBoV} 2$ and $\mathrm{HBoV} 3$. Three $\mathrm{HBoV}$ lineages were illustrated in all four phylogenetic trees (Figure 3).

\section{Discussion}

$\mathrm{HBoV}$ is a novel parvovirus first described in 2005 by Allander and colleagues [8]. Since that time, it has been associated with upper and lower-respiratory tract disease and gastrointestinal illness throughout the world. 
Table 3 Clinical characteristics of HBoV-positive patients

\begin{tabular}{|c|c|c|c|c|}
\hline Characteristics & Single $\mathrm{HBoV}^{\mathrm{a}}$ & Co-pathogens & Total & $\mathrm{p}$ values ${ }^{\mathrm{b}}$ \\
\hline Patients No. & 37 & 28 & 65 & \\
\hline Cough & $34(91.9)$ & $27(96.4)$ & $61(93.8)$ & 0.451 \\
\hline Fever $\left(\geq 38^{\circ} \mathrm{C}\right)$ & $24(64.9)$ & $20(71.4)$ & $44(67.7)$ & 0.575 \\
\hline Abnormal pulmonary breathing sound ${ }^{c}$ & $23(62.2)$ & $12(42.9)$ & $35(53.8)$ & 0.122 \\
\hline Dyspnea & $19(51.4)$ & $11(39.3)$ & $30(46.2)$ & 0.334 \\
\hline Expectoration & $17(45.9)$ & $9(32.1)$ & $26(40.0)$ & 0.261 \\
\hline Snivel & $13(35.1)$ & $10(35.7)$ & $23(35.4)$ & 0.961 \\
\hline Pneumonia & $6(16.2)$ & $13(46.4)$ & $19(29.2)$ & 0.008 \\
\hline Rhinobyon & $5(13.5)$ & $9(32.1)$ & $14(21.5)$ & 0.070 \\
\hline Vomiting & $3(8.1)$ & $3(10.7)$ & $6(9.2)$ & 0.719 \\
\hline Sneeze & $3(8.1)$ & $2(7.1)$ & $5(7.7)$ & 0.885 \\
\hline Pharyngeal discomfort $^{d}$ & $3(8.1)$ & $2(7.1)$ & $5(7.7)$ & 0.885 \\
\hline Poor appetite & $3(8.1)$ & $1(3.6)$ & $4(6.2)$ & 0.451 \\
\hline Chill & $3(8.1)$ & $0(0)$ & $3(4.6)$ & 0.123 \\
\hline Diarrhea & $1(2.7)$ & $2(7.1)$ & $3(4.6)$ & 0.398 \\
\hline Lung markings increasing & $1(2.7)$ & $1(3.6)$ & $2(3.1)$ & 0.841 \\
\hline Headache & $1(2.7)$ & $1(3.6)$ & $2(3.1)$ & 0.841 \\
\hline Myodynia & $2(5.4)$ & $0(0)$ & $2(3.1)$ & 0.211 \\
\hline Debilitation & $1(2.7)$ & $1(3.6)$ & $2(3.1)$ & 0.841 \\
\hline Herpangina & $1(2.7)$ & $0(0)$ & $1(1.5)$ & 0.381 \\
\hline Swirl & $1(2.7)$ & $0(0)$ & $1(1.5)$ & 0.381 \\
\hline
\end{tabular}

${ }^{a}$ Data are No. (\%) of each group, percentages sum to $>100 \%$ because some patients had $>1$ diagnosis.

bStatistical difference between "Single HBoV" and "Co-pathogens"

'Including phlegm rale, wheeze rale, bubbling rale, moist rale, and rhonchi.

${ }^{\mathrm{d}}$ Including pharyngeal dryness, pharyngalgia, and trachyphonia.

Co-pathogens: co-detected with other 16 potential pathogens.

Single HBoV: detected with single HBoV, without other 16 potential pathogens.

However, most studies were focused on young children and infants [9-14], and only a few papers have described the characteristics of $\mathrm{HBoV}$ infection in adult patients $[16,25,26]$. Our study successfully analyzed the characteristics of $\mathrm{HBoV}$-positive samples from ARTI-infected patients with a wide age distribution from Guangzhou, southern China for the first reported time. Similar to previous study [16], the detection rate in pediatric patients $(<18$ years old $)$ was significantly higher than that in adults $(\geq 18$ years old) $(p<0.001)$, and most $\mathrm{HBoV}$-positive patients were $\leq 3$ years old. $\mathrm{HBoV}$ was detected in four adult patients, including 60 and 70 year-old patients. This suggested that older people were also susceptive to $\mathrm{HBoV}$ infection, although at much lower positive rates. Four adult patients also presented with systemic influenza-like symptoms, which might suggest that $\mathrm{HBoV}$ infection in adults is a more complex and serious problem than in children.

While seasonal peaks of $\mathrm{HBoV}$ infection vary among different counties and regions because of climate and other factors, many previous studies suggest a higher detection rate in winter $[27,28]$. In our study, a higher frequency of
HBoV was observed between May and June during the 13month testing period (Figure 2). This result was similar to the report of Choi and colleagues, in which a seasonal peak was observed between May and June [29].

Characteristics of $\mathrm{HBoV}$-positive patients in our study were also similar to previous reports [9-14]. The male: female ratio in the $\mathrm{HBoV}$-positive patients did not differ significantly from the $\mathrm{HBoV}$-negative patients. In all clinical characteristics, seven major symptoms (cough, fever $\left(\geq 38^{\circ} \mathrm{C}\right)$, abnormal pulmonary breath sound, dyspnea, expectoration, snivel and pneumonia) had the highest ratio (ratio > 10\%) (Table 3 ) and were common as URTI and LRTI.

As previous studies [13,29-34], co-detection with other potential pathogens was common in $\mathrm{HBoV}$-positive patients. In this work, $43.1 \%(28 / 65)$ patients were codetected with other 16 potential pathogens, and there would be higher ratio if human rhinovirus were concerned [16]. Furthermore, not only co-pathogens but also single $\mathrm{HBoV}$ groups had a high ratio of major symptoms (Table 3), which might suggest $\mathrm{HBoV}$ is an important pathogen in URTI and LRTI. A statistic 


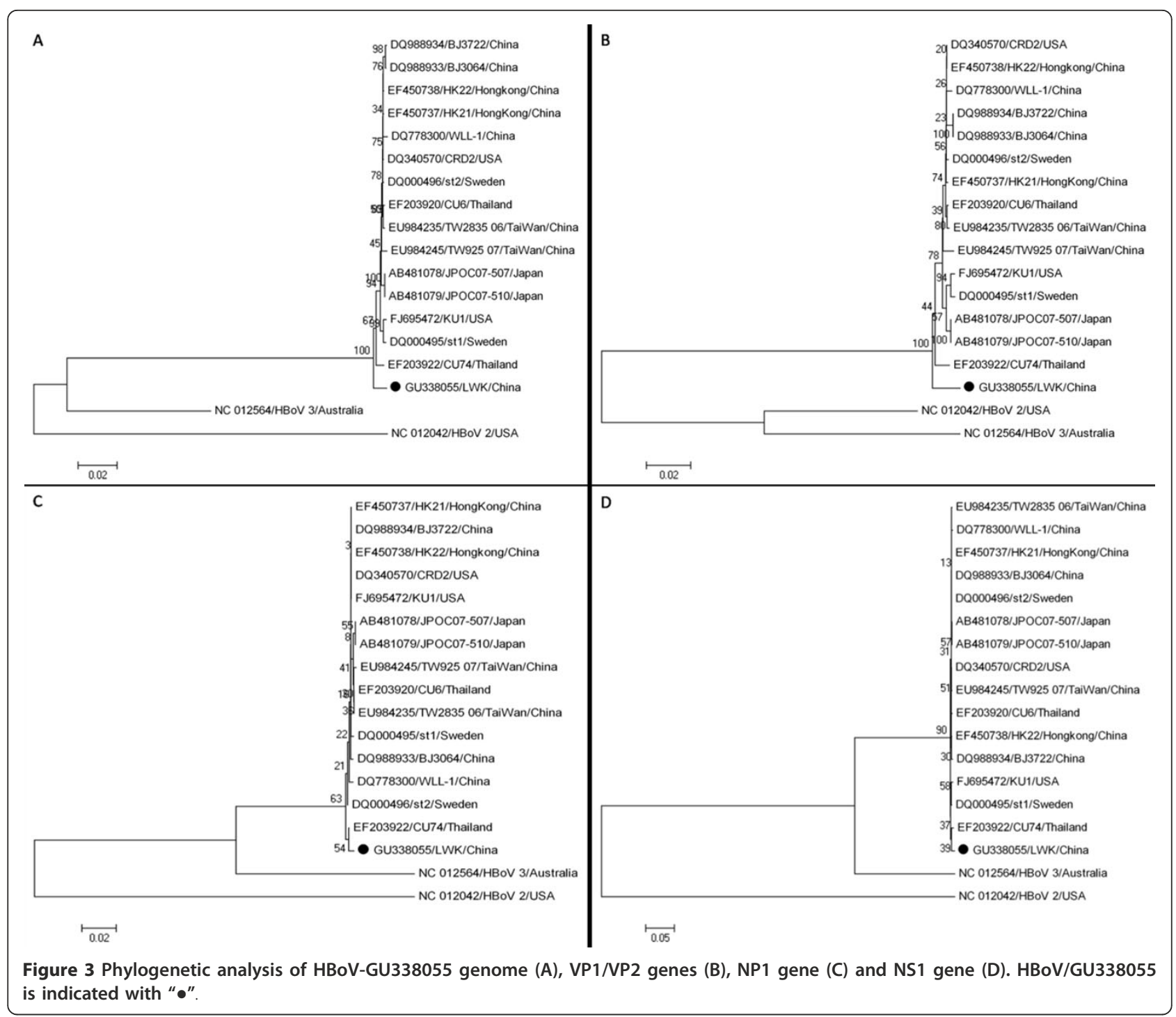

difference was found for the symptom of "pneumonia" between the two groups "Single HBoV" and "Co-pathogens" (Table 3), which might further suggest $\mathrm{HBoV}$ is an important pathogen. Further studies were required to determine whether $\mathrm{HBoV}$ played a causative role in these co-infections or acted as an exacerbation factor.

Before 2009, little variation was found in the surface protein of HBoV (VP1-VP2), and some researchers predicted that $\mathrm{HBoV}$ infection might only occur after the subsequently development of life-long immunity via the neutralization of the target antibody [16]. However, novel types of $\mathrm{HBoV} 2$ and $\mathrm{HBoV} 3$ were described successively in 2009 [23,24], suggested diversity within this group of viruses. Furthermore, we successfully sequenced the complete $\mathrm{HBoV}$ genome (GU338055) for an isolate from an adult patient and phylogenetic analysis revealed the existence of three lineages: group I,
$\mathrm{HBoV}$; group II, HBoV2; group III, $\mathrm{HBoV} 3$, and GU338055 was located in group I.

The frequency and clinical presentations of $\mathrm{HBoV}$ infection vary widely $[9-14,16,25,26]$ and are typically associated with other pathogens [13,29-34]. Such characteristics have subsequently led many scientists to question the role of $\mathrm{HBoV}$ as a potential pathogen. This lack of information is largely because of the inability of $\mathrm{HBoV}$ to grow in standard cell lines [35]. To confirm the effects of $\mathrm{HBoV}$, more studies are required throughout the world, focusing on various aspects of this infection, including epidemiology, serology, molecular biology, in vitro culture and animal models.

\section{Conclusions}

$\mathrm{HBoV}$ was detected from children and adults with ARTI from Guangzhou, southern China, and the features were 
described in this study. $\mathrm{HBoV}$ was confirmed in elderly patients (60 and 70 years old), suggesting that older people were also susceptive to $\mathrm{HBoV}$. All four adult patients with $\mathrm{HBoV}$ positive in this study presented systemic influenza-like symptoms, which potentially suggest that $\mathrm{HBoV}$ infection in adults may develop more serious symptoms than those in children. Phylogenetic analysis suggested that HBoV-GU338055 from an elderly patient is in a single lineage with other HBoVs.

\section{Acknowledgements}

The State Major Infectious Disease Research Program (China Central Government, 2009ZX10004-109) provided financial support for this work.

\section{Author details}

'State Key Laboratory of Respiratory Diseases, Guangzhou Medical University, 1 Kang Da Road, Guangzhou, Guangdong 510230, China. ${ }^{2}$ The First Affiliated Hospital of Guangzhou Medical University, 151 Yan Jiang Road, Guangzhou, Guangdong 510230, China.

\section{Authors' contributions}

RZ and $\mathrm{W}-\mathrm{KL}$ designed the study. W-KL, Q L, H-XL performed the HBoV DNA testing. D-HC, Z-FY and SQ collected clinical data. All authors participated in the data analysis. W-K $L$ and $R Z$ drafted the manuscript. All authors read and approved the final version of this manuscript.

\section{Competing interests}

The authors declare that they have no competing interests.

Received: 27 February 2011 Accepted: 14 December 2011 Published: 14 December 2011

\section{References}

1. van den Hoogen BG, de Jong JC, Groen J, Kuiken T, de Groot R, Fouchier RAM, Osterhaus ADME: A newly discovered human pneumovirus isolated from young children with respiratory tract disease. Nat Med 2001, 7:719-724.

2. Peiris JSM, Lai ST, Poon LLM, Guan Y, Yam LYC, Lim W, Nicholls J, Yee WKS, Yan WW, Cheung MT, Cheng VCC, Chan KH, Tsang DNC, Yung RWH, Ng TK, Yuen KY: Coronavirus as a possible cause of severe acute respiratory syndrome. Lancet 2003, 361:1319-1325.

3. Fouchier RA, Hartwig NG, Bestebroer TM, Niemeyer B, de Jong JC, Simon $\mathrm{JH}$, Osterhaus ADME: A previously undescribed coronavirus associated with respiratory disease in humans. Proc Natl Acad Sci USA 2004, 101:6212-6216.

4. van der Hoek L, Pyrc K, Jebbink MF, Vertheim-Oost W, Berkhout RJM, Wolthers KC, van Dillen PMEW, Kaandorp J, Spaargaren J, Berkhout B: Identification of a new human coronavirus. Nat Med 2004, 10:368-373.

5. Woo PCY, Lau SKP, Tsoi HW, Huang Y, Poon RW, Chu CM, Lee RA, Luk WK, Wong GK, Wong BH, Cheng VC, Tang BS, Wu AK, Yung RW, Chen H, Guan Y, Chan KH, Yuen KY: Clinical and molecular epidemiological features of coronavirus HKU1-associated community-acquired pneumonia. J Infect Dis 2005, 192:1898-1907.

6. Woo PCY, Lau SKP, Chu CM, Chan KH, Tsoi HW, Huang Y, Wong BHL, Poon RWS, Cai JJ, Luk WK, Poon LLM, Wong SSY, Guan Y, Peiris GSM, Yuen KY: Characterization and complete genome sequence of a novel coronavirus, coronavirus HKU1, from patients with pneumonia. J Virol 2005, 79:884-895.

7. Lau SKP, Woo PCY, Chu CM, Yip CCY, Tse H, Tsoi HW, Cheng VCC, Lee P, Tang BSF, Cheung CHY, Lee RA, So LY, Lau YL, Chan KH, Yuen KY: Coronavirus HKU1 and other coronavirus infections in Hong Kong. J Clin Microbiol 2006, 44:2063-2071.

8. Allander T, Tammi MT, Eriksson M, Bjerkner A, Lindell AT, Andersson B: Cloning of a human parvovirus by molecular screening of respiratory tract samples. Proc Natl Acad Sci USA 2005, 102(36):12891-12896.

9. Kesebir D, Vazquez M, Weibel C, Shapiro ED, Ferguson D, Landry ML, Kahn JS: Human bocavirus infection in young children in the United
States: molecular epidemiological profile and clinical characteristics of a newly emerging respiratory virus. J Infect Dis 2006, 194:1276-1282.

10. Fry AM, Lu X, Chittaganpitch M, Peret T, Fischer J, Dowell S, Anderson LJ, Erdman D, Olsen SJ: Human bocavirus: a novel parvovirus pidemiologically associated with pneumonia requiring hospitalization in Thailand. J Infect Dis 2007, 195:1038-1045.

11. Maggi F, Andreoli E, Pifferi M, Meschi S, Rocchi J, Bendinelli M: Human bocavirus in Italian patients with respiratory diseases. J Clin Virol 2007, 38:321-325.

12. Arden KE, McErlean P, Nissen MD, Sloots TP, Mackay LM: Frequent detection of human rhinoviruses, paramyxoviruses, coronaviruses, and bocavirus during acute respiratory tract infections. J Med Virol 2006, 78:1232-1240.

13. Arnold JC, Singh KK, Spector SA, Sawyer MH: Human bocavirus: prevalence and clinical spectrum at a children's hospital. Clin Infect Dis 2006, 43:283-288.

14. Qu XW, Duan ZJ, Qi ZY, Xie ZP, Gao HC, Liu WP, Huang CP, Peng FW, Zheng LS, Hou YD: Human bocavirus infection, People's Republic of China. Emerg Infect Dis 2007, 13(1):165-168.

15. Chieochansin T, Thongmee C, Vimolket L, Theamboonlers A, Poovorawan $Y$ : Human bocavirus infection in children with acute gastroenteritis and healthy controls. Jpn J Infect Dis 2008, 61(6):479-481.

16. Lau SK, Yip CC, Que TL, Lee RA, Au-yeung RKH, Zhou B, So LY, Lau YL, Chan KH, Woo PCY, Yuen KY: Clinical and molecular epidemiology of human bocavirus in respiratory and fecal samples from children in Hong Kong. J Infect Dis 2007, 196(7):986-993.

17. Lee Jl, Chung JY, Han TH, Song MO, Hwang ES: Detection of human bocavirus in children hospitalized because of acute gastroenteritis. $J$ Infect Dis 2007, 196(7):994-997.

18. Albuquerque $M C$, Rocha $L N$, Benati FJ, Soares CC, Maranhão AG, Ramírez ML, Erdman D, Santos N: Human bocavirus infection in children with gastroenteritis, Brazil. Emerg Infect Dis 2007, 13(11):1756-1758.

19. Cheng WX, Jin Y, Duan ZJ, Xu ZQ, Qi HM, Zhang Q, Yu JM, Zhu L, Jin M, Liu N, Cui SX, Li HY, Fang ZY: Human bocavirus in children hospitalized for acute gastroenteritis: a case-control study. Clin Infect Dis 2008, 47(2):161-167.

20. Yu JM, Li DD, Xu ZQ, Cheng WX, Zhang Q, Li HY, Cui SX, Jin M, Yang SH, Fang ZY, Duan ZJ: Human bocavirus infection in children hospitalized with acute gastroenteritis in China. J Clin Virol 2008, 42(3):280-285.

21. Campe $H$, Hartberger $C$, Sing A: Role of human bocavirus infections in outbreaks of gastroenteritis. J Clin Virol 2008, 43(3):340-342.

22. Schildgen O, Muller A, Simon A: Human bocavirus and gastroenteritis. Emerg Infect Dis 2007, 13(10):1620-1621.

23. Kapoor A, Slikas E, Simmonds P, Chieochansin T, Naeem A, Shaukat S, Alam MM, Sharif S, Angez M, Zaidi S, Delwart E: A newly identified bocavirus species in human stool. J Infect Dis 2009, 199(2):196-200

24. Arthur JL, Higgins GD, Davidson GP, Givney RC, Ratcliff RM: A novel bocavirus associated with acute gastroenteritis in Australian children. PLoS Pathog 2009, 5(4):e1000391

25. Bastien N, Brandt K, Dust K, Ward D, Li Y: Human bocavirus infection, Canada. Emerg Infect Dis 2006, 12:848-850.

26. Kupfer B, Vehreschild J, Cornely O, Kaiser R, Plum G, Viazov S, Franzen C, Tillmann RL, Simon A, Müller A, Schildgen O: Severe pneumonia and human bocavirus in adult. Emerg Infect Dis 2006, 12:1614-1616.

27. Chow BD, Huang YT, Esper FP: Evidence of human bocavirus circulating in children and adults, Cleveland, Ohio. J Clin Virol 2008, 43(3):302-306.

28. Bastien N, Chui N, Robinson JL, Lee BE, Dust K, Hart L, Li Y: Detection of human bocavirus in Canadian children in a 1-year study. $J$ Clin Microbiol 2007, 45(2):610-613.

29. Choi EH, Lee HJ, Kim SJ, Eun BW, Kim NH, Lee JA, Lee JH, Song EK, Kim SH, Park JY, Sung JY: The association of newly identified respiratory viruses with lower respiratory tract infections in Korean children, 2000-2005. Clin Infect Dis 2006, 43(5):585-592.

30. Sloots TP, McErlean P, Speicher DJ, Arden KE, Nissen MD, Mackay IM: Evidence of human coronavirus HKU1 and human bocavirus in Australian children. J Clin Virol 2006, 35:99-102.

31. Regamey N, Frey U, Deffernez C, Latzin P, Kaiser L: Isolation of human bocavirus from Swiss infants with respiratory infections. Swiss Paediatric Respiratory Research Group. Pediatr Infect Dis J 2007, 26:177-179.

32. Kaplan NM, Dove W, Abu-Zeid AF, Shamoon HE, Abd-Eldayem SA, Hart CA: Human bocavirus infection among children, Jordan. Emerg Infect Dis 2006, 12:1418-1420. 
33. Foulongne $\mathrm{V}$, Olejnik $Y$, Perez V, Elaerts S, Rodiere M, Segondy M: Human bocavirus in French children. Emerg Infect Dis 2006, 12:1251-1253.

34. Weissbrich B, Neske F, Schubert J, Tollmann F, Blath K, Blessing K, Kreth HW: Frequent detection of bocavirus DNA in German children with respiratory tract infections. BMC Infect Dis 2006, 6:109.

35. Chow BD, Esper FP: The human bocaviurses: a review and discussion of their role in infection. Clin Lab Med 2009, 29(4):695-713.

\section{Pre-publication history}

The pre-publication history for this paper can be accessed here: http://www.biomedcentral.com/1471-2334/11/345/prepub

doi:10.1186/1471-2334-11-345

Cite this article as: Liu et al:: Detection of human bocavirus from

children and adults with acute respiratory tract illness in Guangzhou, southern China. BMC Infectious Diseases 2011 11:345.

\section{Submit your next manuscript to BioMed Central} and take full advantage of:

- Convenient online submission

- Thorough peer review

- No space constraints or color figure charges

- Immediate publication on acceptance

- Inclusion in PubMed, CAS, Scopus and Google Scholar

- Research which is freely available for redistribution

Submit your manuscript at www.biomedcentral.com/submit 